\title{
Complex formation processes of the Yarlung Zangbo ophiolites (Tibet)
}

\author{
QING XIONG ${ }^{1,2 *}$, JIAN-PING ZHENG ${ }^{1}$, HONG-DA ZHENG ${ }^{1}$, \\ WILLIAM L. GRIFFIN ${ }^{2}$, SUZANNE Y. O'REILLY ${ }^{2}$ \\ ${ }^{1}$ GPRM, China Univ. of Geosciences, Wuhan 430074, China \\ (*correspondence: xiongqing@cug.edu.cn) \\ ${ }^{2}$ CCFS \& GEMOC, Macquarie Univ., NSW 2109, Australia
}

The well preserved ophiolites in the $2000-\mathrm{km}$-long Yarlung Zangbo (YZ) suture (South Tibet) provide an outstanding natural laboratory to investigate the formation and evolution of oceanic lithosphere, and the cycling of Earth's mantle. The YZ ophiolites show three segments (eastern, central and western) with variable structures, heterogeneous compositions and complex origins. The eastern ophiolites (e.g., Luobusa, Zedang) are similar to the western ones (e.g., Purang, Dongbo), but quite different from the central ophiolites (Xigaze).

Our previous studies ${ }^{[1-4]}$ show that the eastern $\mathrm{YZ}$ ophiolites record long-term, episodic accretion of oceanic lithosphere in spreading centers of different tectonic settings (i.e., continental margins, subduction zones). Os-Hf-Nd isotopes reveal that different-scale heterogeneities (depleted and enriched) were incorpated into the ophiolitic mantle. Geochemical and microstructural evidence suggests that the oceanic lithosphere experienced multiple melt-rock interaction, complex melt migration and crystallization processes, and rapid recycling of components from deep mantle to shallow lithosphere in subduction zones. The western $\mathrm{YZ}$ ophiolites show two periods of mafic magmatism (middle Jurassic and early Cretaceous), two-layered mantle structure, high- and low-Cr chromitite and dunite systems, and ultrahigh-pressure and super-reduced phases and textures, all similar to those of the eastern YZ ophiolites.

In contrast, the central $\mathrm{YZ}$ ophiolites only show single episode of early Cretaceous magmatism with corresponding formation of oceanic lithospheric mantle, comparable to those formed in slow-spreading mid-ocean ridges or back-arc centers. Recent studies suggest this spreading center rapidly ceased and transformed to a subduction zone, closely after the early Cretaceous production of oceanic lithosphere. In summary, the whole $\mathrm{YZ}$ ophiolites record complex formation processes in the Neo-Tethyan oceanic lithosphere, with the eastern and western segments close to trench while the central segment from the back-arc center. This framework is similar to the giant subduction system in present-day western Pacific.

${ }^{[1]}$ Xiong et al. (2016) EPSL, 438, 57-65; ${ }^{[2]}$ Xiong et al. (2017) G-cubed, 18, 1189-1213; ${ }^{[3]}$ Xiong et al. (2017) CMP, 172:45; ${ }^{[4]}$ Griffin et al. (2016) J Petrol, 57, 655-684. 